\title{
TINJAUAN TERHADAP PERTIMBANGAN HUKUM DALAM PEMBATALAN KEWENANGAN MENTERI DAN GUBERNUR DI DAERAH BERKAITAN DENGAN EXECUTIVE REVIEW PADA PUTUSAN NO. 137/PUU-XIII/2015 DAN NO. 56/PUU-XIV/2016
}

\author{
Rio Dwi Nugroho \\ Mahasiswa Magister Ilmu Hukum Universitas Mataram \\ email :riodwi_23@gmail.com \\ Gatot Dwi Hendro Wibowo \\ Dosen Fakultas Hukum Universitas Mataram \\ Email:gatotdwihendrofh@unram.ac.id \\ Chrisdianto Eko Purnomo \\ Dosen Fakultas Hukum Universitas Mataram \\ Email:chrisdiantofh@unram.ac.id
}

\begin{abstract}
Abstrak
Penelitian ini bertujuan untuk menganalisa pertimbangan hukum hakim Mahkamah Konstitusi dalam Putusan No. 137/PUU-XIII/2015 dan Putusan No. 56/PUU-XIV/2016 yang menghapuskan kewenangan Pemerintah Pusat terkait dengan pembatalan Perda melalui mekanisme executive review sebagaimana tertuang di dalam Pasal 251 UU No. 23 Tahun 2014 Tentang Pemerintahan Daerah. Penelitian ini merupakan penelitian hukum normatif. Menggunakan metode pendekatan perundang-undangan, pendekatan konseptual, dan pendekatan kasus. Teknik pengumpulan bahan dilakukan dengan cara melakukan library research. Berdasarkan hasil penelitian dapat disimpulkan bahwa dasar pertimbangan hukum dalam Putusan MK No. 137/PUU-XIII/2015 dan No. 56/PUU-XIV/2016 telah mengabaikan konvensi ketatanegaraan selama ini mengenai kewenangan executive review terhadap Perda yang dilakukan Pemerintah Pusat serta tidak mempunyai alasan yang cukup kuat untuk membedakan kewenangan executive review terhadap Perda dengan executive review terhadap Perkada.
\end{abstract}

Kata kunci : Executive Review, Kewenangan, Peraturan Perundang-undangan, Putusan Mahkamah Konstitusi.

\section{A. PENDAhULUAN}

Hingga saat ini isu mengenai pemerintahan daerah selalu menjadi topik yang hangat untuk dibicarakan karena luasnya dimensi yang mengisi pemerintahan daerah itu sendiri. Salah satu yang menjadi bagian dalam pemerintahan

1 Penjelasan Pasal 17 Undang-Undang Nomor 23 Tahun 2014 Tentang Pemerintahan Daerah menyatakan kebijakan daerah yang daerah itu adalah berkenaan dengan kebijakan daerah dimana salah satunya adalah Peraturan Daerah. ${ }^{1}$ Seperti halnya pemerintahan daerah, pembahasan mengenai Peraturan Daerah beserta problematika yang mengitarinya akan selalu berkembang searah dengan

dimaksud disini Perda, Perkada, dan keputusan kepala Daerah. 
perkembangan pemikiran, penggunaannya di dalam praktek ketatanegaraan maupun hal-hal lainnya baik langsung atau tidak langsung bersentuhan dengan Peraturan Daerah.

Diantara hal-hal tersebut misalnya dapat dilihat ketika Mahkamah Konstitusi menguji Undang-Undang Nomor 23 Tahun 2014 Tentang Pemerintahan Daerah seperti dalam Putusan No. 137/PUU-XIII/2015 dan No. 56/PUU-XIV/2016 dimana salah satu yang dipersoalkan adalah konstitusionalitas suatu lembaga yang membatalkan Peraturan Daerah. Sebagaimana yang diketahui di dalam Putusan MK No. 137/PUUXIII/2015 telah menghilangkan kewenangan Gubernur (sebagai wakil pemerintah pusat) untuk membatalkan Peraturan Daerah Kabupaten/Kota sedangkan putusan MK No. 56/PUUXIV/2016 telah menghilangkan kewenangan Menteri untuk membatalkan Peraturan Daerah Provinsi. Meskipun amar putusan hanya menyinggung penghapusan kewenangan Menteri dan Gubernur (sebagai wakil pemerintah pusat) dalam membatalkan Peraturan Daerah namun terdapat ruang untuk dilakukan suatu pengkajian secara mendalam. Hal ini dikarenakan putusan MK tersebut memuat suatu pertimbangan hukum yang mempersempit ruang dalam pengendalian norma hukum yang terdapat dalam produk hukum daerah seperti Peraturan Daerah misalnya. Dengan adanya kedua putusan MK tersebut pengendalian norma hukum terhadap Perda yang dilakukan oleh Pemerintah Daerah tidak dapat dilakukan lagi sementara dalam pertimbangan hukumnya pengendalian tersebut masih dimungkinkan dilakukan terhadap Perkada. Oleh karena itu di dalam pembahasan penulis banyak membandingkan mengapa pengendalian norma hukum seperti executive review dapat dilakukan terhadap Perkada sementara terhadap Perda hal tersebut tidak dapat dilakukan. Selain itu penulis juga akan mencoba menggali lebih dengan menganalisis berbagai undang-undang tentang penyelenggaraan pemerintahan daerah selama ini yang dulu pernah berlaku untuk melihat kemungkinan-kemungkinan dapatnya dilakukan executive review karena boleh jadi memang tidak bertentangan dengan Undang-Undang Dasar Negara Republik Indonesia Tahun 1945.

\section{B. METODE PENELITIAN}

Berdasarkan permasalahan yang diangkat dalam penelitian ini maka penelitian ini dikategorikan sebagai penelitian hukum Normatif yang mengkaji norma, asas, maupun nilai-nilai yang terdapat dalam peraturan perundangundangan, yang mencerminkan problematika hukum karena adanya konflik norma. Adapun pendekatan yang dipilih dalam penelitian ini yaitu menggunakan pendekatan undang-undang (statute approach), pendekatan konseptual (conceptual approach) dan pendekatan kasus (case approach). Bahan hukum yang bersumber dari peraturan perundangundangan yang berkaitan dengan masalah yang diteliti antara lain: Undang-Undang Dasar Negara Republik Indonesia Tahun 1945, Undang-Undang Nomor 22 Tahun 1948 Tentang Penetapan Aturan-Aturan Pokok Mengenai Pemerintahan Sendiri Di Daerah-Daerah Yang Berhak Mengatur Dan Mengurus Rumah Tangganya Sendiri, Undang-Undang Nomor 1 Tahun 1957 Tentang Pokok-Pokok Pemerintahan Daerah, Penetapan Peraturan Presiden Nomor 6 Tahun 1959 Tentang Pemerintah Daerah, Undang-Undang Nomor 18 Tahun 1965 Tentang Pokok-Pokok Pemerintahan Daerah, Undang-Undang Nomor 12 Tahun 2011 Tentang Pembentukan Peraturan Perundang-Undangan sebagaimana telah diubah dengan Undang-Undang Nomor 15 Tahun 2019 Tentang Perubahan Atas Undang-Undang Nomor 12 Tahun 2011 Tentang Pembentukan Peraturan Perundang-Undangan, Undang Undang 
Nomor 23 Tahun $2014 \quad$ Tentang Pemerintahan Daerah sebagaimana telah diubah beberapa kali terakhir dengan Undang-Undang Nomor 9 Tahun 2015 Tentang Perubahan Kedua Atas Undang Undang Nomor 23 Tahun 2014 Tentang Pemerintahan Daerah, Putusan Mahkamah Konstitusi Nomor 87/PUU-XIII/2015 tentang Pengujian Undang-Undang Nomor 23 Tahun 2014 Tentang Pemerintahan Daerah, Putusan Mahkamah Konstitusi Nomor 137/PUU-XIII/2015 tentang Pengujian Undang-Undang Nomor 23 Tahun 2014 Tentang Pemerintahan Daerah, Putusan Mahkamah Konstitusi Nomor 56/PUU-XIV/2016 tentang Pengujian Undang-Undang Nomor 23 Tahun 2014 Tentang Pemerintahan Daerah. Dari semua bahan hukum yang berhasil dikumpulkan, kemudian diolah dan dianalisis secara kualitatif dengan maksud untuk memperoleh suatu jawaban dari isu-isu hukum yang ditimbulkan akibat pembatalan kewenangan Pemerintah Pusat melalui Menteri dan Gubernur sebagai wakil Pemerintah Pusat di daerah untuk membatalkan Perda sebagai hasil peninjauan terhadap Putusan Mahkamah Konstitusi Nomor 137/PUU-XIII/2015 dan Nomor 56/PUU-XIV/2016, sehingga diperloleh suatu kesimpulan yang signifikan dengan pokok permasalahan yang diangkat melalui metode deskriptif yaitu dalam bentuk uraian yang dirumuskan dengan pola pikir yang runtun dan logis. Analisis kualitatif dilakukan dengan cara induktif-deduktif, yaitu menarik kesimpulan dari bahan yang sifatnya khusus ke umum untuk memperoleh kejelasan terhadap suatu kebenaran, sehingga memperoleh gambaran yang jelas terkait masalah yang diteliti.

\section{PEMBAHASAN}

\section{Status Hukum Pendelegasian Wewenang dari Peraturan Pemerintah ke Peraturan Pemerintah Lainnya.}

Pada dasarnya pertimbangan hukum menempati posisi yang sangat menentukan dalam suatu putusan karena didalamnya mengandung gambaran pemikiran hakim terhadap suatu kasus yang diputusnya. Jimmly Asshiddiqie misalnya melihat pertimbangan hukum sebagai dasar dalam bagi hakim untuk mengambil putusan. Jika hakim tersebut menjadi bagian dalam suatu persidangan pada kelembagaan Mahkamah Konstitusi maka pertimbangan hukum merupakan dasar untuk mengambil suatu putusan yang bersifat final dan mengikat. Pertimbangan-pertimbangan hukum itulah yang mengantarkan pada kesimpulan amar putusan yang ditulis pada bagian tersendiri. ${ }^{2}$

Sebenarnya pertimbangan hukum bukanlah satu-satunya yang dapat dijadikan dasar suatu putusan. Suatu fakta yang muncul dalam persidangan juga merupakan hal yang harus mendapatkan perhatian seorang hakim karena dengannya hakim dapat memberikan putusan yang seadiladilnya. Dalam Undang-Undang Nomor 24 Tahun 2003 Tentang Mahkamah Konstitusi fakta bersama dengan pertimbangan hukum merupakan dasar dari suatu putusan. Misalnya apabila dilihat dalam Pasal 48 ayat (2) secara keseluruhan berbunyi sebagai berikut: "Setiap putusan Mahkamah Konstitusi harus memuat: a. kepala putusan berbunyi: "DEMI KEADILAN BERDASARKAN KETUHANAN YANG MAHA ESA"; $b$. identitas pihak; c. ringkasan permohonan; d. pertimbangan terhadap fakta yang terungkap dalam persidangan; $e$.
2 Jimly Asshiddiqie, Hukum Acara Pengujian Undang-Undang, Konstitusi Press, Jakarta, 2006, hal. 284 
pertimbangan hukum yang menjadi dasar putusan; f. amar putusan; dan g. hari, tanggal putusan, nama hakim konstitusi, dan panitera. ${ }^{3}$

Kemudian jika Pasal 48 ayat (2) dikaitkan dengan pertimbangan hukum sendiri maka ada dua hal yang dapat dipetik. Pertama pertimbangan hukum menjadi bagian yang tidak terpisahkan di dalam putusan. Adanya keharusan dimuatnya pertimbangan hukum dalam putusan menunjukkan segala sesuatu baru layak dianggap sebagai putusan yang berdasarkan hukum dan keadilan apabila terdapat pertimbangan hukum didalamnya. Kedua pertimbangan hukum mengantarkan suatu perkara pada putusan akhir dari para hakim. Inilah yang dimaksud dengan pertimbangan hukum sebagai dasar putusan dimana didalamnya hakim mempunyai pertimbangan-pertimbangan yuridis yang mendalam yang merupakan dasar argumentasi hakim pada amar putusan yang dibuatnya. Seperti yang disampaikan Jimly Asshiddiqie yang juga telah disampaikan sebelumnya bahwa pertimbangan hukum itulah yang akan mengantarkan kesimpulan amar putusan. ${ }^{4}$

Sebagaimana yang diketahui Putusan MK No. 137/PUU-XIII/2015 dan No. 56/PUU-XIV/2016 telah membatalkan kewenangan Gubernur (sebagai wakil pemerintah pusat) untuk membatalkan Peraturan Daerah Kabupaten/Kota dan Menteri untuk membatalkan Peraturan Daerah Provinsi. Misalnya hal ini terlihat dalam amar putusan angka 4 pada Putusan No. 137/PUU-XIII/2015 yang menyebutkan Menyatakan frasa "Perda Kabupaten/Kota dan” dalam Pasal 251 ayat (2) dan ayat (4), frasa "Perda Kabupaten/Kota dan/atau" dalam Pasal 251 ayat (3), dan frasa "penyelenggara Pemerintah Daerah kabupaten/kota tidak

3 Indonesia, Undang-Undang Tentang Mahkamah Konstitusi, UU No. 24 Tahun 2003, LN No. 98 Tahun 2003, TLN. 4316. dapat menerima keputusan pembatalan Perda Kabupaten/Kota dan" dan frasa "Perda Kabupaten/Kota atau" dalam Pasal 251 ayat (8) Undang-Undang Nomor 23 Tahun 2014 Tentang Pemerintahan Daerah (lembaran negara Republik Indonesia Tahun 2014 Nomor 244 dan Tambahan Lembaran Negara Republik Indonesia Nomor 5587) bertentangan dengan Undang-Undang Dasar Negara Republik Indonesia Tahun 1945 dan tidak mempunyai kekuatan hukum mengikat.

Demikian pula dengan amar putusan angka 4 Putusan No. 56/PUU-XIV/2016 yang menyebutkan Menyatakan frasa "Perda Provinsi dan" dalam Pasal 251 ayat (1) dan ayat (4), dan frasa "Perda Provinsi dan" dalam Pasal 251 ayat (7), serta Pasal 251 ayat (5) Undang-Undang Nomor 23 Tahun 2014 Tentang Pemerintahan Daerah (lembaran negara Republik Indonesia Tahun 2014 Nomor 244 dan Tambahan Lembaran Negara Republik Indonesia Nomor 5587) bertentangan dengan Undang-Undang Dasar Negara Republik Indonesia Tahun 1945 dan tidak mempunyai kekuatan hukum mengikat.

Sejak keluarnya kedua putusan tersebut maka kewenangan Pemerintah Pusat yang diwakili oleh Menteri dan Gubernur untuk membatalkan Perda otomatis sudah tidak ada lagi. Apabila Pemerintah Pusat dengan berdasarkan kewenangan yang diberikan oleh Pasal 251 Undang-Undang Nomor 23 Tahun 2014 Tentang Pemerintahan Daerah tetap membatalkan Perda maka sama artinya pembatalan tersebut tidak sah menurut hukum karena kewenangan yang dijalankan telah menyalahi ketentuan Undang-Undang Dasar Negara Republik Indonesia Tahun 1945. Artinya kewenangan Menteri berdasarkan Pasal 251 ayat (1) UU No. 23 Tahun 2014 untuk membatalkan Perda

4 Jimly Asshiddiqie, Hukum Acara Pengujian Undang-Undang, Op. Cit, hal. 284 
Provinsi dan kewenangan Gubernur sebagai wakil Pemerintah Pusat berdasarkan Pasal 251 ayat (2) untuk membatalkan Perda Kabupaten/Kota adalah kewenangan yang tidak bersumber pada hukum dasar Peraturan Perundang-Undangan. ${ }^{5}$

Untuk mengetahui apa yang mendasari keluarnya amar putusan yang demikian tentunya pertimbangan hukum hakim MK dalam kedua putusan tersebut dapat menjawab semua pertanyaan tersebut. Dengan melihat pertimbangan hukum hakim MK maka akan tergambarkan bagaimana argumentasi hakim dalam menguji Pasal 251 UU No. 23 Tahun 2014 yang memberikan kewenangan kepada Menteri dan Gubernur sebagai wakil Pemerintah Pusat di daerah dalam membatalkan Perda. Melalui pertimbangan hukum tersebut hakim MK menyampaikan pendapat hukumnya mengenai konstitusionalitas kewenangan yang diberikan dalam Pasal 251 yang dengan pasal tersebut Menteri dan Gubernur berwenang membatalkan Perda.

Perlu diketahui dalam pertimbangan hukum Putusan MK No. 137/PUUXIII/2015 sebenarnya alasan atau dalil pemohon yang dipertimbangkan bukan hanya berkenaan pengujian Perda sebagaimana yang diatur dalam Pasal 251 UU No. 23 Tahun 2014 Tentang Pemerintahan Daerah. Pokok permohonan yang juga dipertimbangkan oleh hakim MK yaitu berkenaan dengan konstitusionalitas pembagian klasifikasi urusan pemerintahan. Oleh karena itu hakim MK juga menguji pasal-pasal lain selain Pasal 251 di dalam UU Pemerintahan Daerah. Selain itu pula berkenaan dengan konstitusionalitas Pasal 251 hakim MK bukan hanya menguji kewenangan dalam membatalkan Perda tapi juga prihal pengujian kewenangan Menteri dan Gubernur sebagai wakil Pemerintah Pusat dalam membatalkan Perkada.
Sehingga konstitusionalitas dari pembatalan Perda dan Perkada serta kontitusionalitas pembagian klasifikasi urusan pemerintahan merupakan pokok permasalahan yang dipertimbangkan secara khusus dan mendalam oleh hakim MK.

Sementara itu Putusan MK No. 56/PUU-XIV/2016 pokok permasalahan yang dipertimbangkan hakim MK dalam pertimbangan hukum hanyalah konstitusionalitas pembatalan Perda dan Perkada. Artinya hanya Pasal 251 dalam UU No. 23 Tahun 2014 yang diuji oleh hakim MK dalam putusan ini. Oleh karena itu pertimbangan hukum dalam Putusan MK No. 56/PUU-XIV/2016 banyak merujuk pertimbangan hukum yang terdapat di dalam Putusan MK No. 137/PUU-XIII/2015. Hal ini sama artinya untuk memahami pendapat atau argumentasi hukum hakim MK dalam Putusan Putusan MK No. 56/PUUXIV/2016 maka penting untuk memahami terlebih dahulu Putusan MK No. 137/PUUXIII/2015.

Jika kita membaca pertimbangan hukum dalam Putusan MK No. 137/PUUXIII/2015 maka ada dua hal yang mendasari pertimbangan hukum hakim MK yang mengakibatkan pembatalan atas kewenangan Menteri dan Gubernur sebagai wakil Pemerintah Pusat untuk membatalkan Perda yang didasarkan pada Pasal 251 UU No. 23 Tahun 2014 Tentang Pemerintahan Daerah. Pertama, pemberian kewenangan pembatalan Perda Provinsi dan Perda Kabupaten/Kota kepada Menteri berdasarkan Pasal 251 ayat (1) dan ayat (3) serta pembatalan Perda Kabupaten/Kota kepada Gubernur berdasarkan Pasal 251 ayat (2) UU No. 23 Tahun 2014 Tentang Pemerintahan Daerah menurut hakim MK telah menyimpangi logika dan bangunan

\footnotetext{
${ }^{5}$ Pasal 251 ayat (1) UU No. 23 Tahun 2014

Tentang Pemerintahan Daerah.
} 
negara hukum. ${ }^{6}$ Dengan demikian Pasal 251 telah melanggar Pasal 1 ayat (3) UndangUndang Dasar Negara Republik Indonesia Tahun 1945 yang menegaskan "Negara Indonesia adalah negara hukum.",7

Kedua, hal apa yang telah diatur dalam Pasal 251 menurut hakim MK telah menegasikan peran dan fungsi MA sebagai lembaga yang berwenang melakukan pengujian peraturan perundang-undang dibawah undang-undang terhadap undangundang. Mahkamah Agung sebagai salah satu lembaga yang mempunyai kewenangan judicial review didasarkan pada Pasal 24A ayat (1) Undang-Undang Dasar Negara Republik Indonesia Tahun 1945 yang menyebutkan "Mahkamah Agung berwenang mengadili pada tingkat kasasi, menguji peraturan perundang-undangan di bawah undang-undang terhadap undangundang, dan mempunyai wewenang lainnya yang diberikan oleh undang-undang."

Kedua hal ini yaitu menyimpangi logika dan bangunan negara hukum dan menegasikan peran dan fungsi MA merupakan pendapat hukum hakim MK terhadap keberlakukan Pasal 251 ayat (1), ayat (2), dan ayat (3) UU No. 23 Tahun 2014 Tentang Pemerintahan Daerah. Dengan pendapat yang demikian maka menurut hakim MK Pasal 251 ayat (1), ayat (2), dan ayat (3) telah bertentangan Pasal 1 ayat (3) dan Pasal 24A ayat (1) UndangUndang Dasar Negara Republik Indonesia Tahun 1945. Oleh karena itu kedua hal ini dapat disebut sebagai hal yang mendasari pertimbangan hukum hakim MK atas pokok permohonan pemohon mengenai pengujian konstitusionalitas Pasal 251 ayat (1), ayat (2), dan ayat (3) yang berdasarkan pemeriksaan di persidangan terbukti bertentangan dengan konstitusi. Hal ini berarti pula kewenangan Menteri untuk

6 Mahkamah Konstitusi Republik Indonesia, Putusan Nomor 137/PUU-XIII/2015, 5 April 2017, hal. 205 membatalkan Perda Provinsi dan Perda Kabupaten/Kota serta kewenangan Gubernur untuk membatalkan Perda Kabupaten/Kota terbukti melanggar Undang-Undang Dasar Negara Republik Indonesia Tahun 1945.

Tentunya ada alasan mengapa hakim MK sampai berpendapat bahwa Pasal 251 ayat (1), ayat (2), dan ayat (3) UU No. 23 Tahun 2014 Tentang Pemerintahan Daerah telah menyimpangi logika dan bangunan negara hukum dan menegasikan peran dan fungsi MA. Di dalam pertimbangan hukum Putusan MK No. 137/PUU-XIII/2015 ada 3 prinsip yang dipertimbangkan sebelum mempertimbangkan konstiusionalitas Pasal 251 ayat (1), ayat (2), dan ayat (3). Adapun ketiga prinsip tersebut yaitu prinsip Negara Kesatuan Republik Indonesia, prinsip otonomi daerah dan desentralisasi, serta prinsip kekuasaan kehakiman dan negara hukum.

Hakim MK berpandangan bahwa di dalam prinsip NKRI daerah-daerah merupakan bagian integral dari Republik Indonesia, sehingga mempunyai hak yang sama untuk memperoleh atau menciptakan kemajuan pembangunan dan kesejahteraan masyarakatnya. Menurut hakim MK mengenai prinsip NKRI yaitu bentuk negara yang dalam hal ini berbentuk republik merupakan suatu kesepakatan nasional sebagaimana ditegaskan dalam Pasal 1 ayat (1) Undang-Undang Dasar Negara Republik Indonesia Tahun 1945. Bahkan apabila dilihat ketentuan Pasal 37 ayat (5) Undang-Undang Dasar Negara Republik Indonesia Tahun 1945 yang menyebutkan terhadap negara kesatuan tidak dapat dilakukan perubahan menunjukkan bentuk negara republik secara

7 Republik Indonesia, Undang-Undang Dasar Negara Republik Indonesia Tahun 1945, Bab I, Pasal 1 ayat (3).

${ }^{8}$ Ibid, Bab IX, Pasal 24A ayat (1). 
kontitusional merupakan keputusan politik yang final. ${ }^{9}$

Prinsip selanjutnya yaitu prinsip otonomi daerah dan desentralisasi oleh hakim MK cukup mempertimbangkan banyak hal didalamnya. Dalam pandangan hakim MK di dalam prinsip otonomi daerah dan desentralisasi pemerintahan pusat dan daerah merupakan suatu kesatuan organisasi yang sudah semestinya harus saling menghargai, saling mendukung, dan saling memperkuat satu sama lain. Hakim MK juga mengingatkan bahwa titik berat otonomi daerah dengan prinsip otonomi seluas-luasnya yang dilaksanakan oleh Provinsi, Kabupaten dan Kota merupakan suatu konsensus otonomi daerah. ${ }^{10}$

Dalam pertimbangan hukum Putusan MK No. 137/PUU-XIII/2015 melalui prinsip kekuasaan kehakiman dan negara hukum hakim MK hendak menunjukkan dua hal. Pertama, konsekuensi dari pilihan negara hukum adalah tegaknya judicial review di dalam suatu negara. Kedua, pengujian peraturan perundang-undangan yang tingkatannya berada dibawah undang-undang hanya dapat dilakukan oleh Mahkamah Agung. Kedua hal inilah yang mengisi pandangan hakim MK berkenaan dengan prinsip kekuasaan kehakiman dan negara hukum yang nantinya menjadi pondasi dari alasan hakim MK untuk menunjukkan bahwa Pasal 251 ayat (1), ayat (2), dan ayat (3) inkonstitusional. Adapun alasan tersebut yaitu executive review tidak dapat dilakukan terhadap Perda karena hal itu merupakan bentuk dari upaya pengujian.

Menurut hakim MK salah satu syarat tegaknya negara hukum itu adalah keberadaan judicial review di dalam suatu negara sebagaimana tersurat dalam Pasal 1 ayat (3) Undang-Undang Dasar Negara Republik Indonesia Tahun 1945. Sebagai

9 Mahkamah Konstitusi Republik Indonesia, Putusan Nomor 137/PUU-XIII/2015, Op.Cit, hal. 196-197 nafas utama dalam negara hukum maka peraturan perundang-undangan hanya layak diuji oleh suatu lembaga yustisi yang dalam perkataan lain suatu produk hukum hanya absah apabila diuji melalui institusi hukum yang bernama pengadilan. Hal ini selaras dengan teori pemencaran dan pemisahan kekuasaan yang berujung pada mekanisme saling mengawasi dan mengimbangi (checks and balances). ${ }^{11}$

Bagi hakim MK pengujian Perda merupakan kewenangan mutlak Mahkamah Agung karena hal tersebut bukan saja didasarkan Pasal 24A ayat (1) UndangUndang Dasar Negara Republik Indonesia Tahun 1945 tapi juga ditegaskan oleh turunan dari pasal tersebut. Berdasarkan ketentuan di dalam Undang-Undang Nomor 12 Tahun 2011 Tentang Pembentukan Peraturan Perundang-Undangan menurut hakim MK pengujian Perda merupakan kewenangan MA yang tidak dapat dilakukan lembaga lainnya. Hakim MK menegaskan Perda apabila didasarkan pada UU No. 12 Tahun 2011 Tentang Pembentukan Peraturan PerundangUndangan merupakan salah satu dari bentuk peraturan perundang-undangan yang hierarkinya berada di bawah undangundang. Sepanjang suatu norma hukum itu dituangkan dalam bentuk peraturan perundang-undangan seperti yang diatur dalam UU No. 12 Tahun 2011 Tentang Pembentukan Peraturan PerundangUndangan yang secara kedudukan berada di bawah undang-undang, maka sebagaimana ditentukan dalam Pasal 24A ayat (1) Undang-Undang Dasar Negara Republik Indonesia Tahun 1945, pengujiannya hanya dapat dilakukan oleh MA, bukan oleh lembaga lainnya. ${ }^{12}$ Turunan dari pasal dalam konstitusi tersebut yang mengatur kewenangan pengujian peraturan perundang-undangan di bawah undang-
${ }^{10}$ Ibid, hal. 198

${ }^{11}$ Ibid, hal. 203

${ }^{12}$ Ibid, hal.204 
undang yang salah satunya yaitu Perda telah diatur dalam Pasal 9 ayat (2) UU No. 12 Tahun 2011 Tentang Pembentukan Peraturan Perundang-Undangan yang menyebutkan "Dalam hal suatu Peraturan Perundang-undangan di bawah UndangUndang diduga bertentangan dengan Undang-Undang, pengujiannya dilakukan oleh Mahkamah Agung."

Adanya frasa "bukan oleh lembaga lainnya" yang melakukan pengujian Perda menunjukkan hakim MK hendak menempatkan kewenangan tersebut merupakan kewenangan ekslusif MA. Dengan pengaturan judicial review sebagaimana diatur dalam Pasal 24A ayat (1) Undang-Undang Dasar Negara Republik Indonesia Tahun 1945 dan Pasal 9 ayat (2) UU No. 12 Tahun 2011 Tentang Pembentukan Peraturan PerundangUndangan, hakim MK berpendapat satusatunya kewenangan pengujian Perda adalah pengujian yang dilakukan oleh MA atau dengan kata lain hanya judicial review (pengujian yang dilakukan oleh lembaga yudisial) dan bukan pengujian lainnya yang dilakukan oleh lembaga lain sebagai suatu pengujian yang sah diakui dalam sistem ketatanegaraan Indonesia.

Pendirian hakim MK terhadap Pasal 24A ayat (1) Undang-Undang Dasar Negara Republik Indonesia Tahun 1945 dan Pasal 9 ayat (2) UU No. 12 Tahun 2011 Tentang Pembentukan Peraturan PerundangUndangan inilah yang menjadi salah satu dari beberapa petunjuk yang memperlihatkan pengujian Perda melalui executive review tidak diakui dalam sistem ketatanegaraan Indonesia. Apabila ada lembaga yang melakukan pengujian Perda selain MA maka lembaga tersebut telah melanggar prinsip kekuasaan kehakiman dan negara hukum yang telah diatur di dalam Undang-Undang Dasar Negara Republik Indonesia Tahun 1945 maupun peraturan turunannya. Hal inilah sebagaimana yang telah disebutkan sebelumnya bahwa pelaksanaan executive review terhadap Perda merupakan bentuk pelanggaran terhadap konstitusi yang dengan alasan ini hakim MK berpendapat Pasal 251 ayat (1), ayat (2), dan ayat (3) telah menyimpangi logika dan bangunan negara hukum.

Adapun mengenai pengaturan pembatalan Perda yang dilakukan oleh lembaga yusitisi, tidak saja tidak terdapat di dalam bab mengenai pembatalan Perda namun juga tidak ada di seluruh ketentuan UU Pemerintahan Daerah, maka hal ini menunjukkan pembentuk undang-undang telah melabrak ketentuan Pasal 24A ayat (1) Undang-Undang Dasar Negara Republik Indonesia Tahun 1945. Dengan alasan ini hakim MK berpendapat Pasal 251 ayat (1), ayat (2), dan ayat (3) telah menegasikan peran dan fungsi MA sebagai lembaga yang berwenang melakukan pengujian peraturan perundang-undangan di bawah undangundang seperti halnya Perda.

Sebenarnya alasan yang disampaikan oleh hakim MK berkenaan dengan tidak adanya kewenangan untuk membatalkan Perda melalui executive review oleh lembaga eksekutif menimbulkan pertanyaan akan konsistensi pemikiran karena terlihat adanya perlakuan berbeda terhadap Perkada. Seperti yang dijelaskan sebelumnya ada 3 (tiga) pokok permasalahan yang dipertimbangkan secara khusus dan mendalam oleh hakim MK dalam Putusan MK No. 137/PUUXIII/2015 yaitu konsitusionalitas pembatalan Perda dan Perkada serta kontitusionalitas pembagian klasifikasi urusan pemerintahan.

Khusus mengenai konstitusionalitas pembatalan Perkada hakim MK mempertimbangkan bahwa baik mekanisme pembatalan Perkada maupun mekanisme keberatan terhadap pembatalannya merupakan bagian dari mekanisme pengawasan yang dilakukan oleh Presiden atau Menteri dan Gubernur sebagai wakil Pemerintah Pusat kepada daerah. Adapun alasannya yaitu karena 
Perkada hanya dibentuk oleh kepala daerah sebagai satuan bestuur dalam rangka untuk mengimplementasikan Perda dan undangundang, khususnya UU Pemerintahan Daerah berkenaan dengan urusan pemerintahan. ${ }^{13}$

Berdasarkan atas hal tersebut maka dalam kerangka negara kesatuan Pemerintah Pusat sebagai satuan bestuur yang lebih tinggi berwenang untuk melakukan pembatalan terhadap Perkada. Menjadi pertanyaan, apakah pembatalan yang termasuk dalam mekanisme pengawasan Pemerintah Pusat ini dilakukan melalui upaya executive review? Ternyata jawabannya adalah "iya" karena menurut pertimbangan hukum Putusan MK No. 56/PUU-XIV/2016 bahwa pembatalan Perkada yang dalam hal ini Peraturan Bupati/Wali Kota dilakukan melalui mekanisme executive review. Dalam pertimbangan hukum putusan tersebut, hakim MK berpendapat bahwa mekanisme kontrol yang demikian merupakan lingkup fungsi administrasi negara (bestuursfunctie) yang dapat saja dilakukan dan tidak bertentangan dengan Undang-Undang Dasar Negara Republik Indonesia Tahun 1945. ${ }^{14}$ Dalam hal ini berdasarkan pertimbangan hukum Putusan MK No. 56/PUU-XIV/2016 hakim MK telah memberikan pengertian executive review terhadap Perkada sebagai mekanisme kontrol Pemerintah Pusat, yaitu suatu pengertian yang sangat bertolak belakang dengan pengertian executive review terhadap Perda.

Dengan demikian menjadi jelaslah persoalannya bahwa terdapat pengertian yang berbeda antara executive review yang dilakukan terhadap Perda serta executive review terhadap Perkada yang diberikan oleh hakim MK. Executive review yang dilakukan terhadap Perda menurut hakim

${ }^{13}$ Ibid, hal.207
MK merupakan upaya pengujian yang dianggap telah melangkahi kewenangan MA dengan judicial review nya sehingga menyimpangi logika dan bangunan negara hukum. Adapun executive review yang dilakukan Pemerintah Pusat terhadap Perkada bagi hakim MK bukanlah merupakan pengujian melainkan bentuk dari pengawasan satuan bestuur yang lebih tinggi terhadap satuan bestuur yang lebih rendah dalam hal ini kepala daerah. Oleh karena itu executive review terhadap Perkada dapat saja dilakukan dan tidak bertentangan dengan Undang-Undang Dasar Negara Republik Indonesia Tahun 1945 karena semata-mata menjalankan fungsi kontrol dalam ranah administrasi negara.

Putusan yang satu menunjukkan setiap pembatalan Perda oleh lembaga eksekutif harus dinyatakan sebagai upaya pengujian yaitu executive review dan terhadap pembatalan Perkada hanyalah bagian dari mekanisme pengawasan dan bukan pengujian. Sementara putusan yang lain menyatakan terhadap pembatalan Perkada oleh lembaga eksekutif dilakukan melalui mekanisme executive review dimana sebagai mekanisme kontrol Pemerintah Pusat. Singkatnya Putusan MK No. 137/PUU-XIII/2015 secara jelas menyatakan executive review terhadap Perda sebagai upaya pengujian sedangkan Putusan MK No. 56/PUU-XIV/2016 menyatakan executive review terhadap Perkada bukan merupakan upaya pengujian melainkan suatu mekanisme kontrol semata. Jika di dalam pertimbangan hukum mengenai pembatalan Perkada pada Putusan MK No. 137/PUU-XIII/2015 tidak menggunakan istilah executive review melainkan pembatalan dari mekanisme pengawasan maka Putusan MK No. 56/PUU-XIV/2016 dengan jelas

14 Mahkamah Konstitusi Republik Indonesia, Putusan Nomor 56/PUU-XIV/2016, 14 Juni 2018, hal. 97 
menyebutkan bahwa pembatalan itu dilakukan dengan menggunakan mekanisme executive review. Atas dasar hal tersebut bagi yang membaca dan mempelajari kedua putusan ini bisa saja mempertanyakan konsistensi pemikiran hakim MK berkenaan dengan executive review peraturan perundang-undangan yang berada di bawah undang-undang.

Untuk lebih memastikan apakah hakim MK telah merumuskan pertimbangan hukum yang konsisten baik di dalam pertimbangan hukum dalam satu putusan yang sama maupun dengan pertimbangan hukum pada putusan yang lain, maka perlu untuk melihat bagaimana pendapat hukum hakim MK mengenai Perda dan Perkada sehingga memunculkan dua makna dalam executive review yaitu pengujian dan bukan pengujian. Sebelum diuraikan lebih jauh mengenai hal ini maka penulis terlebih dahulu perlu untuk menegaskan bahwa prinsip kekuasaan kehakiman dan negara hukum dipertimbangkan oleh hakim MK adalah untuk menguji Pasal 251 yang didalamnya memuat pengaturan pembatalan Perda maupun Perkada.

$\begin{gathered}\text { Seperti } \\ \text { sebelumnya }\end{gathered}$ bahwa
hakim
mempertimbangkan prinsip kekuasaan kehakiman dan negara hukum adalah untuk mempertegas kedudukan MA sebagai satusatu lembaga yang berwenang untuk melakukan pengujian peraturan perundangundangan yang tingkatannya berada di bawah undang-undang. Hal itu terbukti manakala hakim MK menggunakan Pasal 24A ayat (1) Undang-Undang Dasar Negara Republik Indonesia Tahun 1945 dan Pasal 9 ayat (2) UU No. 12 Tahun 2011 Tentang Pembentukan Peraturan PerundangUndangan untuk menyatakan lembaga lain selain MA tidak berwenang melakukan

15 Pasal 7 ayat (1) dan Pasal 8 ayat (1) Undang-Undang Nomor 12 Tahun 2011 Tentang Pembentukan Peraturan Perudang-Undangan. pengujian peraturan perundang-undangan di bawah undang-undang. Adanya pernyataan bahwa "... pengujian hanya dapat dilakukan oleh Mahkamah Agung, bukan oleh lembaga lain ..." menunjukkan executive review yang dilakukan oleh lembaga lain menyalahi prinsip kekuasaan kehakiman dan negara hukum.

Hakim MK ketika menjelaskan prinsip tersebut yang digunakan untuk menyampaikan pandangan mengenai maksud dari Pasal Pasal 24A ayat (1) Undang-Undang Dasar Negara Republik Indonesia Tahun 1945 dan Pasal 9 ayat (2) UU No. 12 Tahun 2011 Tentang Pembentukan Peraturan PerundangUndangan, sama sekali tidak menyebutkan bahwa hal itu ditujukkan hanya untuk Perda saja. Hakim MK menggunakkan prinsip kekuasaan kehakiman dan negara hukum adalah untuk menyampaikan pendapat hukum mereka berkenaan dengan kewenangan MA dalam melakukan pengujian terhadap semua peraturan perundang-undangan di bawah undangundang yang tidak sebatas pada Perda saja. Hakim MK bahkan dengan jelas menyampaikan bahwa sepanjang suatu norma hukum itu dituangkan dalam bentuk peraturan sebagaimana dimaksud dalam UU No. 12 Tahun 2011 Tentang Pembentukan Peraturan PerundangUndangan telah sangat nyata menunjukkan bahwa yang dimaksud ialah semua peraturan perundang-undangan yang terdapat dalam Pasal 7 ayat (1) dan Pasal 8 ayat (1) dari undang-undang tersebut. ${ }^{15}$ Selain itu juga perlu diingatkan bahwa pokok permohonan pemohon tidak saja mengenai pengujian konstitusionalitas pembatalan Perda namun juga konstitusionalitas pembatalan perkada dimana prinsip kekuasaan kehakiman dan 
negara hukum digunakan untuk mempertimbangkan keduanya.

Menegaskan prinsip kekuasaan kehakiman dan negara hukum digunakan untuk mempertimbangkan kewenangan pembatalan Perda maupun pembatalan Perkada adalah penting untuk menyampaikan "pesan" bahwa penyimpangan terhadap logika dan bangunan negara hukum dikarenakan adanya executive review yang melangkahi kewenangan judicial review MA. Penyebutan pasal-pasal di dalam peraturan perundang-undangan seperti Pasal 24A ayat (1) Undang-Undang Dasar Negara Republik Indonesia Tahun 1945 dan Pasal 9 ayat (2) UU No. 12 Tahun 2011 Tentang Pembentukan Peraturan PerundangUndangan menunjukkan hakim MK berpendapat semua peraturan perundangundangan di bawah undang-undang itu yang berwenang untuk menguji adalah Mahkamah Agung. Apakah itu pembatalan Perda ataupun pembatalan Perkada sepanjang itu adalah pengujian maka itu adalah kewenangan Mahkamah Agung.

Persoalannya pembatalan oleh Pemerintah Pusat terhadap Perda itu disebut executive review yang merupakan pengujian sedangkan terhadap pembatalan Perkada merupakan bagian mekanisme executive review yang bukan pengujian. Berdasarkan hal tersebut sangat terlihat hakim MK hendak melepaskan executive review terhadap Perkada dari ikatan prinsip kekuasaan kehakiman dan negara hukum. Dengan melakukan ini executive review terhadap Perkada tidak perlu terikat dengan konsekuensi berlakunya Pasal 24A ayat (1) Undang-Undang Dasar Negara Indonesia Tahun 1945 dan Pasal 9 ayat (2) UU No. 12 Tahun 2011 Tentang Pembentukan Peraturan Perundang-Undangan bahwa pengujian hanya dapat dilakukan oleh MA dan bukan lembaga lainnya. Padahal seperti yang telah diuraikan sebelumnya prinsip kekuasaan kehakiman dan negara hukum yang dipergunakan oleh hakim MK dalam pertimbangan hukum Putusan No. 137/PUU-XIII/2015 tidak pernah menyebutkan hanya dipergunakan terbatas hanya pada jenis peraturan perundangundangan tertentu saja. Dengan memisahkan istilah executive review terhadap Perda sebagai pengujian di satu sisi dan executive review terhadap Perkada bukan pengujian sehingga tidak perlu terikat dengan konsekuesi Pasal 24A ayat (1) Undang-Undang Dasar Negara Indonesia Tahun 1945 dan Pasal 9 ayat (2) UU No. 12 Tahun 2011 Tentang Pembentukan Peraturan PerundangUndangan di sisi yang lain, yang pada akhirnya executive review terhadap Perkada tidak terikat dengan prinsip kekuasaan kehakiman dan negara hukum, hakim MK telah memperlihatkan ketidakonsistenan dalam menggunakan prinsip-prinsip konstitusional.

Selain tidak konsisten dalam menggunakan prinsip konstitusional, hakim MK juga tidak konsisten dalam menggunakan syarat berlaku mengikat umum terhadap Perda dan Perkada. Apabila melihat pertimbangan hukum yang mempertimbangkan kewenangan pembatalan Perda didalamnya terlihat bahwa hakim MK menolak adanya executive review dikarenakan Perda itu sudah mempunyai daya keberlakuan mengikat umum dan merupakan produk legislatif. Kontrol dapat dilakukan sepanjang masih berupa rancangan bukan sebagai suatu peraturan yang sudah berlaku dan mengikat. Oleh karena itu Pemerintah Pusat masih dibolehkan untuk melakukan executive abstract preview yaitu kewenangan untuk mengawasi rancangan suatu peraturan perundang-undangan.

Apabila alasan yang dipergunakan hakim MK adalah bahwa review tidak dapat dilakukan karena Perda telah berlaku mengikat untuk umum maka alasan ini sangat lemah. Hal ini dikarenakan Perkada sebagi salah satu diantara berbagai bentuk peraturan yang diakui oleh UU No. 12 
Tahun 2011 Tentang Pembentukan Peraturan Perundang-Undangan pun telah berlaku mengikat untuk umum. Sepanjang suatu peraturan telah disahkan ataupun ditetapkan maka jenis yang semula berupa rancangan akan berubah menjadi peraturan perundang-undangan baik Peraturan Pemerintah, Peraturan Presiden, Peraturan Daerah, Peraturan Kepala Daerah dan sebagainya. Adapun semua peraturan perundang-undangan sepanjang yang telah disahkan ataupun ditetapkan tersebut telah melalui proses pengundangan maka telah mempunyai kekuatan mengikat untuk umum. ${ }^{16}$

Perkada memang tidak disebutkan dalam hierarki peraturan perundangundangan sebagaimana yang disebutkan dalam Pasal 7 ayat (1) UU No. 12 Tahun 2011 Tentang Pembentukan Peraturan Perundang-Undangan namun bukan berarti kedudukannya dalam sistem hukum nasional serta kekuatan mengikatnya sama sekali tidak ada. Pasal 8 ayat (1) dalam undang-undang ini telah menegaskan ada banyak peraturan perundang-undangan selain yang tersebut dalam Pasal 7 ayat (1) yang salah satunya yaitu peraturan yang ditetapkan oleh Gubernur dan Bupati/ Walikota. Untuk mempertegas kedudukannya dalam sistem hukum nasional serta bagaimana kekuatan mengikatnya untuk itulah Pasal 8 ayat (2) dalam UU No. 12 Tahun 2011 diatur. Pasal ini menyatakan "Peraturan Perundangundangan sebagaimana dimaksud pada ayat (1) diakui keberadaannya dan mempunyai kekuatan hukum mengikat sepanjang diperintahkan oleh Peraturan Perundang-undangan yang lebih tinggi atau dibentuk berdasarkan kewenangan. "

Berdasarkan pada Pasal 8 ayat (2) dalam UU No. 12 Tahun 2011

${ }^{16}$ Republik Indonesia, Undang-Undang RI Nomor 12 Tahun 2011 Tentang Pembentukan Peraturan Perundang-Undangan, Bab IX, Pasal 87. menunjukkan meskipun Perkada sebagai salah satu peraturan yang diakui dalam sistem hukum nasional belum tentu mempunyai hukum mengikat apabila sebelumnya tidak memenuhi salah satu dari dua syarat yaitu mengikat sepanjang diperintahkan oleh peraturan perundangundangan yang lebih tinggi dan mengikat apabila dibentuk berdasarkan kewenangan. ${ }^{17}$ Artinya Perkada telah mempunyai kekuatan mengikat sepanjang diperintahkan oleh peraturan perundangundangan yang secara kedudukan berada diatas Perkada seperti undang-undang, PP, Perpres ataupun Perda. Perkada juga mempunyai kekuatan mengikat apabila yang diatur didalamnya merupakan kewenangan yang memang dimiliki oleh Gubernur, Bupati atau Walikota yang sebelumnya telah diatur dalam peraturan perundang-undangan. Jadi eksistensi Perkada sebagai salah satu jenis peraturan perundang-undangan di Indonesia tidak diragukan keberadaannya namun apabila syarat mengikat umum sebagai sebagaimana yang diatur dalam Pasal 8 ayat (2) salah satunya tidak dipenuhi maka jika diuji di pengadilan Perkada tersebut dapat dinyatakan tidak mempunyai kekuatan hukum yang mengikat.

Oleh karena itu merupakan suatu pendapat yang salah untuk menyatakan bahwa executive review terhadap Perda tidak dapat dilakukan dengan alasan bahwa Perda telah berlaku dan mengikat untuk umum. Hal ini hanya akan menunjukkan adanya dualisme pertimbangan hukum sebab terhadap Perkada yang juga mempunyai sifat berlaku mengikat umum semenjak diundangkan-kecuali bila ditentukan lain pada ketentuan penutupexecutive review tenyata dapat juga dilakukan oleh Pemerintah Pusat. Apabila

${ }^{17}$ Republik Indonesia, Undang-Undang RI Nomor 12 Tahun 2011 Tentang Pembentukan Peraturan Perundang-Undangan, Penjelasan Pasal 8 ayat (2). 
hanya mendasari pada sifat suatu peraturan yaitu berlaku mengikat umum maka jika executive review terhadap Perda tidak dapat dilakukan maka terhadap Perkada pun seharusnya tidak dapat dilakukan. Hal ini jauh lebih tepat karena lebih memberikan pegangan mengenai executive review yang dilakukan terhadap peraturan perundangundangan. Meskipun pernyataan ini lebih konsisten namun analisa apakah memang benar executive review terhadap Perda tidak dapat dilakukan Pemerintah Pusat memang belum dilakukan.

Persoalannya sekarang apakah memang benar executive review apabila dilakukan terhadap peraturan perundangundangan yang telah dinyatakan berlaku mengikat umum tidak dapat dilakukan. Sepanjang pembahasan sebelumnya memang hal ini belum dilakukan sebab yang baru dianalisis mengenai kedudukan Perkada sebagai salah satu jenis peraturan perundang-undangan yang seperti halnya Perda juga mempunyai daya keberlakuan mengikat umum. Dari hasil analisis tersebut kita dapat melihat bagaimana hakim MK dalam Putusan No. 137/PUU-XIII/2015 tidak konsisten membuat pertimbangan hukum mengenai executive review terhadap peraturan yang mempunyai kekuatan mengikat dari contoh kasus Perda dan Perkada. Sekarang yang harus dilakukan adalah menganalisis dengan menajamkan persoalan apakah executive review terhadap peraturan perundang-undangan yang mempunyai daya ikat umum dapat dilakukan dan tidak bertentangan dengan prinsip kekuasaan kehakiman dan negara hukum maupun prinsip kedaulatan rakyat. Apabila hal tersebut dimungkinkan berarti hakim MK telah salah membuat pertimbangan hukum yang menyatakan executive review terhadap Perda tidak dapat dilakukan dengan alasan mempunyai daya laku yang mengikat umum. Sebab apabila hal ini tidak dilakukan maka kita harus menerima begitu saja bahwa executive review terhadap Perda-yang merupakan inti dari penelitian-tidak dapat dilakukan karena bertentangan dengan prinsip-prinsip mendasar yang terdapat di dalam konstitusi.

Pada saat pembahasan awal mengenai prinsip kekuasaan kehakiman dan negara hukum telah disebutkan bahwa di dalam pertimbangan hukum Putusan MK No. 137/PUU-XIII/2015, hakim MK berpandangan bahwa pengujian terhadap peraturan perundang-undangan selain undang-undang sebagaimana jenisnya diatur di dalam UU No. 12 Tahun 2011 Tentang Pembentukan Peraturan Perundang-Undangan hanya dapat dilakukan oleh MA dan bukan oleh lembaga lainnya. Berdasarkan pertimbangannya yang demikian hakim MA melihat bahwa pengaturan pengujian peraturan perundangundangan yang kedudukannya di bawah undang-undang yang terdapat dalam Pasal 24A ayat (1) Undang-Undang Dasar Negara Republik Indonesia Tahun 1945 dan Pasal 9 ayat (2) UU No. 12 Tahun 2011 Tentang Pembentukan Peraturan PerundangUndangan adalah kewenangan ekslusif MA yang tidak dapat dilakukan oleh lembaga lainnya. Apabila ada peraturan perundangundangan yang memberikan kewenangan kepada lembaga lain di luar MA untuk melakukan pengujian peraturan perundangundangan yang berada di bawah undangundang maka itu artinya telah melanggar prinsip kekuasaan kehakiman dan negara hukum.

Jika dikaitkan mengenai pandangan hakim MA mengenai Pasal 24A ayat (1) Undang-Undang Dasar Negara Republik Indonesia Tahun 1945 dan Pasal 9 ayat (2) UU No. 12 Tahun 2011 Tentang Pembentukan Peraturan PerundangUndangan maka jawaban atas pertanyaan mengapa hakim $\mathrm{MK}$ berpendapat executive review terhadap peraturan yang mengikat umum tidak dapat dilakukan seperti halnya terhadap Perda yaitu karena melakukan executive review terhadap peraturan yang demikian merupakan langkah pengujian yang bukan merupakan kewenangan 
lembaga eksekutif. Dengan jawaban ini maka kita telah mempersempit analisis selanjutnya yang harus dilakukan yaitu executive review merupakan pengujian ataukah bukan pengujian. Untuk itu penulis merasa perlu menguraikan mengenai sejarah pembatalan Perda oleh Pemerintah Pusat yang diatur dalam peraturan perundang-undangan khususnya undangundang yang mengatur penyelenggaraan pemerintahan daerah yang pernah berlaku selama ini. Hal ini dilakukan untuk menunjukan bahwa pembatalan Perda oleh Pemerintah Pusat bukanlah suatu yang baru dilakukan serta untuk menarik "benang merah" mengenai kemungkinankemungkinan executive review dapat dilakukan dan sebenarnya tidaklah bertentangan dengan Undang-Undang Dasar Negara Republik Indonesia Tahun 1945.

Sebenarnya apabila dilihat dari rumusan Pasal 24A ayat (1) UndangUndang Dasar Negara Republik Indonesia Tahun 1945 dan Pasal 9 ayat (2) UU No. 12 Tahun 2011 Tentang Pembentukan Peraturan Perundang-Undangan sangat jelas bahwa ini adalah kewenangan yang berupa judicial review. Hal ini disebabkan lembaga yang melakukan pengujian hanya menyebutkan Mahkamah Agung. Semantara apabila dilihat ketentuan yang memberikan kewenangan untuk membatalkan Perda dan Perkada di dalam UU No. 23 Tahun 2014 Tentang Pemerintahan Daerah adalah bentuk dari kewenangan executive review karena lembaga yang membatalkannya adalah bagian dari cabang kekuasaan eksekutif yang berada dibawah Presiden. Apabila dilihat dari sejarah perundang-undangan yang ada tindakan executive review merupakan bagian yang tidak terpisahkan dalam penyelenggaraan ketatanegaraan Indonesia khususnya penyelenggaraan pemerintahan daerah. Sejak orde lama berkuasa dimana tindakan pembatalan terhadap produk hukum daerah yang dilakukan oleh organ pusat telah diatur di dalam perundang-undangan pemerintahan daerah pada masa itu. Mulai UndangUndang Nomor 22 Tahun 1948 Tentang Penetapan Aturan-Aturan Pokok Mengenai Pemerintahan Sendiri Di Daerah-Daerah Yang Berhak Mengatur Dan Mengurus Rumah Tangganya Sendiri, UndangUndang Nomor 1 Tahun 1957 Tentang Pokok-Pokok Pemerintahan Daerah, Penpres 6 Tahun 1959 Tentang Pemerintah Daerah, dan Undang-Undang Nomor 18 Tahun 1965 Tentang Pokok-Pokok Pemerintahan Daerah upaya executive review menjadi pokok atau bagian penting untuk mengawasi jalannya pemerintahan daerah. ${ }^{18}$

Begitu pula di masa orde baru berkuasa executive review juga mendapat tempat di dalam peraturan perundangundangan. Pada masa orde baru berkuasa hanya ada satu undang-undang yang mengatur mengenai penyelenggaraan pemerintahan daerah yaitu Undang-Undang Nomor 5 Tahun 1974 Tentang PokokPokok Pemerintahan Di Daerah. Pembatalan yang dilakukan merupakan upaya Pemerintah di masa orde baru dalam rangka melakukan pengawasan terhadap produk hukum yang dibentuk oleh Pemerintah Daerah. Hal ini didorong karena adanya keinginan untuk menjamin terwujudnya keserasian penyelenggaraan tugas pemerintahan antara Pemerintah Pusat dan Pemerintah Daerah. Adapun produk hukum yang dilakukan pengawasan disini yaitu Peraturan Daerah dan Keputusan Kepala Daerah. Pengaturan executive review di dalam undang-undang ini misalnya dapat dilihat dalam Pasal 70 ayat (1) yang menyatakan Peraturan Daerah dan atau Keputusan Kepala 
Daerah yang bertentangan dengan kepentingan umum, peraturan perundangundangan atau Peraturan Daerah tingkat atasnya ditangguhkan berlakunya atau dibatalkan oleh pejabat yang berwenang. Pejabat yang berwenang membatalkan Perda berdasarkan Undang-Undang Nomor 5 Tahun 1974 Tentang Pokok-Pokok Pemerintahan Daerah diatur kewenanganya menurut tingkatan daerah yaitu Menteri untuk daerah tingkat I dan Gubernur untuk daerah tingkat II. ${ }^{19}$

Di dalam rezim perundangundangan pemerintahan daerah orde reformasipun pelaksanaan executive review yang dilakukan Pemerintah Pusat terhadap produk hukum daerah masih tetap dipertahankan. Undang-Undang Nomor 22 Tahun 1999 Tentang Pemerintahan Daerah merupakan undang-undang pertama yang dikeluarkan di masa orde reformasi yang mengatur tata cara penyelenggaraan pemerintahan daerah dengan status mengganti undang-undang sebelumnya yaitu UU No. 5 Tahun 1974 Tentang Pokok-Pokok Pemerintahan Di Daerah. Dalam rezim UU No. 22 Tahun 1999 Tentang Pemerintahan Daerah, pengesahan Perda dan Keputusan Kepala Daerah oleh pejabat berwenang yang lebih tinggi tidak ada sehingga tidak dikenal adanya upaya penolakan untuk mengesahkan terhadap Perda dan Keputusan Kepala Daerah yang wujudnya masih berupa rancangan. Artinya hanya ada tindakan executive review dan bukan executive preview atau pengawasan prepentif dalam undang-undang ini dan sekaligus memberikan ciri unik dibandingkan model pengawasan terhadap produk hukum daerah dari undang-undang sebelumnya dan setelahnya. Di dalam rezim perundang-undangan pemerintahan daerah orde reformasipun pelaksanaan executive review yang dilakukan Pemerintah Pusat terhadap produk hukum daerah masih tetap

${ }^{19}$ Undang-Undang Nomor 5 Tahun 1974 Tentang Pokok-Pokok Pemerintahan Di Daerah dipertahankan. Undang-Undang Nomor 22 Tahun 1999 Tentang Pemerintahan Daerah merupakan undang-undang pertama yang dikeluarkan di masa orde reformasi yang mengatur tata cara penyelenggaraan pemerintahan daerah dengan status mengganti undang-undang sebelumnya yaitu UU No. 5 Tahun 1974 Tentang Pokok-Pokok Pemerintahan Di Daerah. Dalam rezim UU No. 22 Tahun 1999 Tentang Pemerintahan Daerah, pengesahan Perda dan Keputusan Kepala Daerah oleh pejabat berwenang yang lebih tinggi tidak ada sehingga tidak dikenal adanya upaya penolakan untuk mengesahkan terhadap Perda dan Keputusan Kepala Daerah yang wujudnya masih berupa rancangan. Artinya hanya ada tindakan executive review dan bukan executive preview atau pengawasan prepentif dalam undang-undang ini dan sekaligus memberikan ciri unik dibandingkan model pengawasan terhadap produk hukum daerah dari undang-undang sebelumnya dan setelahnya.

Undang-Undang Nomor 32 Tahun 2004 Tentang Pemerintahan Daerah dikeluarkan untuk menggantikan UU No. 22 Tahun 1999 Tentang Pemerintahan Daerah akibat adanya perubahan yang mendasar dalam sistem ketatanegaraan Indonesia yang diatur dalam UndangUndang Dasar Negara Republik Tahun 1945. Salah satu perubahan mendasar tersebut yaitu adanya kewenangan konstitusional bagi MA untuk menjalankan pengujian peraturan perundang-undangan di bawah undang-undang terhadap undangundang. Adanya kewenangan MA yang demikian dalam Undang-Undang Dasar Negara Republik Tahun 1945 turut mempengaruhi penyelenggaraan pemerintahan daerah khususnya berkaitan dengan eksistensi Perda sebagai salah satu dari produk hukum daerah. Berkorelasi dengan kewenangan konstitusional MA

terdapat dalam Bab III Bagian Keenambelas Paragraf II Pasal 70. 
tersebut, dalam UU No. 32 Tahun 2004 Tentang Pemerintahan Daerah terdapat aturan yang memberikan hak kepada daerah untuk mengajukan keberatan atas pembatalan Perda yang dilakukan Pemerintah kepada Mahkamah Agung. Pengaturan norma yang demikian merefleksikan keunikan dalam UU No. 32 Tahun 2004 Tentang Pemerintahan Daerah dibandingkan dengan undang-undang sebelumnya maupun setelahnya yang saat ini masih berlaku dalam hal ini UU No. 23 Tahun 2014 Tentang Pemerintahan Daerah.

Pengaturan mengenai executive review dalam UU No. 32 Tahun 2004 Tentang Pemerintahan Daerah hanya tegas menyebutkan tindakan tersebut ditujukan terhadap Perda. Sementara terhadap Perkada dan Keputusan Kepala Daerah hanya disebutkan hal-hal yang diatur didalamnya dilarang bertentangan dengan kepentingan umum, Perda, dan peraturan perundang-undangan yang lebih tinggi. ${ }^{20}$ Hal ini berbeda dengan undang-undang sebelumnya dimana baik Perda maupun Perkada terdapat pengaturan yang tegas dapat dilakukan pembatalan. Misalnya saja UU No. 1 Tahun 1957 Tentang PokokPokok Pemerintahan Daerah yang berlaku di masa orde lama mengatur mengenai pembatalan yang dapat dilakukan baik terhadap Keputusan Dewan Perwakilan Rakyat Daerah maupun terhadap Keputusan Dewan Pimpinan Daerah. ${ }^{21}$ Adapun yang dimaksud dengan Keputusan Dewan Perwakilan Rakyat Daerah itu dapat berupa peraturan yang berwujud Perda sedangkan Kuputusan Dewan Pemerintah Daerah tidak lain layaknya serupa Perkada di masa berlakunya UU No. 32 Tahun 2004 Tentang Pemerintahan Daerah. ${ }^{22}$ Bahkan UU No. 22 Tahun 1999 Tentang Pemerintahan Daerah

20 Undang-Undang RI Nomor 32 Tahun 2004 Tentang Pemerintahan Daerah, Bab VI, Pasal 146 yang berlaku di masa-masa awal reformasi executive review merupakan jalan satusatunya untuk mengendalikan atau mengawasi produk hukum daerah karena memang hanya mengenal upaya pembatalan dimana yang dibatalkan tersebut disebutkan dengan jelas dilakukan terhadap Perda dan Keputusan Kepala Daerah baik yang bersifat mengatur maupun yang berupa penetapan.

UU No. 23 Tahun 2014 Tentang Pemerintahan Daerah merupakan undangundang pengganti dari UU No. 32 Tahun 2004 Tentang Pemerintahan Daerah. Undang-undang terbaru ini diharapkan mampu lebih menciptakan sinergi yang lebih baik lagi di segala macam aspeknya antara Pemerintah Pusat dan Pemerintahan Daerah yang semasa undang-undang sebelumnya kurang mampu mewujudkannya. Salah satu dari aspek yang perlu disinergikan yaitu mendorong sinergitas antara kebijakan pusat dan kebijakan daerah yang masing-masing tertuang dalam peraturan perundangundangan di level pusat dan daerah. Oleh karena itu norma, standar, prosedur, dan kriteria yang disusun oleh kementerian/lembaga pemerintah nonkementerian merupakan salah satu kunci untuk mewujudkan sinergitas kebijakan pusat dan daerah karena didalamnya terdapat pedoman sebagai rujukan yang jelas baik bagi pusat maupun daerah dalam menyelenggarakan urusan pemerintahan serta pembinaan dan pengawasan. Dalam hal pengawasan yang dilakukan salah satunya berupa executive review yang dapat membatalkan Perda dan Perkada.

Dari sisi tindakan executive review UU No. 23 Tahun 2014 Tentang

${ }^{21}$ Undang-Undang RI Nomor 1 Tahun 1957 Tentang Pokok-Pokok Pemerintahan Daerah, Bab VII, Bagian II, Pasal 64

22 Pasal 45 UU No. 1 Tahun 1957 Tentang Pokok-Pokok Pemerintahan Daerah. 
Pemerintahan Daerah terdapat perubahan yang jauh lebih tegas dibandingkan UU No. 32 Tahun 2004 Tentang Pemerintahan Daerah yang berlaku sebelumnya. Pola executive review yang dilakukan terhadap Perda merupakan executive review yang luas sebagaimana yang pernah berlaku dimasa undang-undang yang mengatur penyelenggaraan pemerintahan daerah di masa orde lama dan orde baru. Dalam melakukan pengawasan UU No. 23 Tahun 2014 Tentang Pemerintahan Daerah tidak lagi menggunakan istilah klarifikasi sebagaimana undang-undang yang sebelumnya berlaku. Tindakan evaluasi terhadap rancangan Perda masih tetap dilakukan namun tidak menghalangi untuk dilakukan executive review terhadapnya ketika telah ditetapkan sebagai Perda. Artinya semua Perda baik yang pernah dilakukan evaluasi ketika masih berupa rancangan ataupun yang langsung tanpa proses evaluasi dapat saja dibatalkan apabila bertentangan dengan kepentingan umum, kesusilaan, dan peraturan perundang-undangan yang lebih tinggi. Adapun tindakan evaluasi yang dilakukan terhadap rancangan Perda sedikit diperluas yaitu terhadap hal-hal yang mengatur RPJPD, RPJMD, APBD, perubahan APBD, pertanggungjawaban pelaksanaan APBD, pajak daerah, retribusi daerah, dan tata ruang daerah. Kemudian tidak seperti halnya UU No. 32 Tahun 2004 Tentang Pemerintahan Daerah yang tidak tegas mengatur executive review terhadap Perkada dalam undang-undang ini menyebutkan secara jelas pembatalan dapat dilakukan baik terhadap Perda maupun terhadap Perkada. ${ }^{23}$

23 Undang-Undang RI Nomor 23 Tahun 2014 Tentang Pemerintahan Daerah, Bab IX, Bagian Ketiga, Pasal 251 ayat (1) dan ayat (2).

24 UU No. 22 Tahun 1948 Tentang Penetapan Aturan-Aturan Pokok Mengenai Pemerintahan Sendiri Di Daerah-Daerah Yang Berhak Mengatur Dan Mengurus Rumah Tangganya Sendiri, Penpres UU No. 6 Tahun 1959
Namun ada satu hal yang mungkin bisa dianggap sebagai kekurangan UU No. 23 Tahun 2014 Tentang Pemerintahan Daerah berkenaan dengan pengawasan yang dilakukan Pemerintah terhadap Perda dan Perkada yaitu tidak adanya pengaturan untuk mengajukan keberatan pembatalan ke lembaga pengadilan. Apabila dilihat dari konstruksi rumusan Pasal 249 sampai dengan 252 yang mengatur prihal pembatalan Perda dan Perkada tidak ada satupun yang menyebutkan adanya lembaga pengadilan untuk terlibat ketika ada keberatan terhadap pembatalan yang dilakukan Pemerintah Pusat. Tidak seperti di dalam UU No. 32 Tahun 2004 Tentang Pemerintahan Daerah yang meletakan kewenangan penyelesaian sengketa keberatan pembatalan tersebut kepada lembaga pengadilan yang dalam hal ini yaitu MA, UU No. 23 Tahun 2014 Tentang Pemerintahan Daerah justru memberikan kewenangan tersebut tetap di dalam ranah kekuasaan eksekutif.

Berdasarkan uraian-uraian ini dapat dipastikan pembatalan Perda merupakan suatu hal yang tidak asing dilakukan dalam sejarah ketatanegaraan RI khususnya dalam penyelenggaraan pemerintahan daerah. Semua undang-undang yang pernah berlaku yang telah diuraikan sebelumnya merupakan sekelompok undang-undang yang terlahir dari dasar konstitusional yang berlainan namun meyakani satu prinsip konstitusional yang sama yaitu prinsip pengawasan dalam hubungan pusat dan daerah yang dilaksanakan salah satunya dalam bentuk pembatalan Perda. ${ }^{24}$ Prinsip ini menjadi pegangan terselenggaranya urusan pemerintahan di daerah dari masa ke

Tentang Pemerintah Daerah, UU No. 18 Tahun 1965 Tentang Pokok-Pokok Pemerintahan Daerah, UU No. 5 Tahun 1974 Tentang Pokok-Pokok Pemerintahan di Daerah menggunakan dasar konstitusional Pasal 18 Undang-Undang Dasar Negara Republik Indonesia Tahun 1945. UU No. 1 Tahun 1957 Tentang Pokok-Pokok Pemerintahan Daerah menggunakan dasar konstitusional Pasal 89, 
masa Pemerintah dari orde lama hingga orde reformasi saat ini.

Pengawasan dalam hubungan Pemerintah Pusat dan daerah seolah-olah telah menjadi implikasi wajib terhadap pilihan dari bentuk negara kesatuan yang hanya mengenal satu negara yang tunggal sifatnya sehingga hanya ada satu saja pemerintahan yang berpuncak pada pemerintahan pusat yang mampu menentukan bagaimana bentuk dan susunan pemerintahan daerah melalui pengaturan dalam undang-undang. Oleh karena itu daerah tidak mungkin melepaskan diri dari campur tangan pusat meskipun daerah mempunyai kewenangan mengatur dan mengurus urusan daerahnya dengan inisiatif sendiri karena memang sejak semula kekuasaan itu merupakan milik pusat yang telah diserahkan ke daerah. Oleh karena itu pusat mempunyai kewenangan untuk melakukan pengawasan terhadap urusan pemerintahan yang telah diserahkan kepada daerah.

Apapun pilihan konstitusi yang dipergunakan sebagai sumber hukum tertinggi penyelenggaraan pemerintahan daerah sepanjang pilihan bentuk negaranya adalah negara kesatuan maka Pemerintah Pusat masih berwenang penuh untuk mengendalikan daerah dalam bentuk pengawasan. Perjalanan ketatanegaraan Indonesia telah membuktikan meskipun berganti-gantinya konstitusi selama negara kesatuan menjadi pilihan sebagai bentuk negara Indonesia, pengawasan pusat terhadap daerah selalu dimunculkan di dalam undang-undang yang merupakan turunan norma kontitusi yang mengatur pemerintahan daerah. Rezim undangundang pemerintahan daerah sejak masa orde lama hingga orde reformasi saat ini

Pasal 131, Pasal 132 Undang-Undang Dasar Sementara Republik Indonesia 1950. Adapun UU No. 22 Tahun 1999 Tentang Pemerintahan Daerah, UU No. 32 Tahun 2004 Tentang Pemerintahan Daerah, dan UU No. 23 Tahun 2014 Tentang selalu memuat pengawasan preventif dan pengawasan represif meskipun tidak selalu kedua pengawasan itu dijalankan bersamasama. Hal yang menarik hampir selalu di dalam undang-undang tersebut pengawasan ditujukan terhadap produk hukum daerah baik dampaknya bisa berupa penolakan pengesahan suatu peraturan maupun pembatalan peraturan. Agaknya pengesahan ataupun penolakan pengesahan serta pembatalan peraturan perundangundangan yang dikeluarkan daerah merupakan implikasi yang melekat dengan konsep pengawasan yang diatur di dalam undang-undang berkenaan dengan pemerintahan daerah.

Hal ini menandakan bahwa di dalam undang-undang pemerintahan daerah pendekatan executive review yang dijalankan selama ini lebih berupa pengawasan dalam hal ini yang sifatnya represif yang bisa berakibat pada pembatalan suatu kebijakan daerah seperti pada Perda misalnya. Pengaturan pengawasan yang dilakukan terhadap Perda maupun terhadap bentuk kebijakan daerah lainnya yang terdapat di dalam undangundang ternyata merupakan pilihan kebijakan pusat yang paling logis hingga saat ini untuk memelihara negara kesatuan, disamping dari esensi dari negara kesatuan yang memang menghendaki pengawasan di dalamnya. Mulai dari UU No. 22 Tahun 1948 Tentang Penetapan Aturan-Aturan Pokok Mengenai Pemerintahan Sendiri Di Daerah-Daerah Yang Berhak Mengatur Dan Mengurus Rumah Tangganya Sendiri yang merupakan undang-undang organik pemerintahan daerah yang pertama hingga UU No. 23 Tahun 2014 Tentang Pemerintahan Daerah yang saat ini berlaku, pembatalan suatu Perda merupakan

Pemerintahan Daerah menggunakan dasar konstitusional Pasal 18 dari perubahan UndangUndang Dasar Negara Republik Indonesia Tahun 1945 , 
implikasi dari pengawasan represif yang dilakukan Pemerintah Pusat. Bahkan UU No. 22 Tahun 1999 Tentang Pemerintahan Daerah menjadikan pengawasan represif terhadap Perda dan Keputusan Kepala Daerah baik yang sifatnya pengaturan maupun penetapan sebagai satunya-satunya model pengawasan sebagai wujud dari mempercayakan seluruhnya jalannya otonomi luas kepada daerah untuk mengeluarkan peraturan tanpa perlu melalui prosedur pengesahan terlebih dahulu atau pengawasan preventif. Executive review terhadap Perda dan kebijakan daerah lainnya dalam rezim perundang-undangan pemerintahan daerah merupakan pengawasan dan pengawasan tersebut bukan merupakan turunan dari kewenangan lembaga yang menyelenggarakan kekuasaan negara lainnya. Artinya executive review dalam rezim undangundang pemerintahan daerah sama sekali tidak mempunyai keterkaitan dengan Pasal 24A ayat (1) Undang-Undang Dasar Negara Republik Indonesia Tahun 1945 yang menjadi sumber kewenangan judicial review Mahkamah Agung.

Kenyataan yang ada-dalam konteks hukum nasional tentunya-bahwa executive review dikaitkan dengan pengujian hanyalah dikenal dalam doktrin dan bukan terlahir dari sistem perundang-undangan nasional. Dalam doktrin ilmu hukum yang berkembang executive review merupakan bagian dari hak menguji (toetsingrecht) disamping pengujian lainnya seperti judicial review dan legislative review. Jimly Assihiddiqie melihat toetsingrecht merupakan hak menguji yang tidak saja dilaksanakan oleh lembaga yudisial tapi juga dilakukan cabang kekuasaan legislatif dan eksekutif. Oleh lembaga mana hak menguji itu dilakukan akan menentukan penyebutannya misalnya executive review jika hak menguji itu diberikan kepada

25 Jimly Asshiddiqie, Hukum Acara Pengujian Undang-Undang, Op. Cit, hal. 2 pemerintah, legislative review jika hak menguji dilakukan lembaga parlemen, dan judicial review jika hak menguji itu dijalankan oleh lembaga peradilan. $^{25}$ Semantara executive review dalam sistem perundang-undangan nasional berkenaan dengan pemerintahan daerah tidak dikaitkan dengan pengujian melainkan pengawasan sehingga istilah asing (belanda) yang dipergunakan tidak menggunakan toetsingrecht atau hak uji melainkan toezichtrecht atau hak pengawasan.

Penggunaan istilah toezingrecht atau hak pengawasan pernah disebutkan di dalam UU No. 22 Tahun 1948 Tentang Penetapan Aturan-Aturan Pokok Mengenai Pemerintahan Sendiri Di Daerah-Daerah Yang Berhak Mengatur Dan Mengurus Rumah Tangganya Sendiri. Sebagaimana yang diketahui undang-undang ini menerapkan model pengawasan preventif sekaligus juga represif. Dalam penjelasan Pasal 42 ditemukan istilah preventief toezingrecht yang merupakan hak pengesahan dan juga repressief toezingrecht yang merupakan hak pembatalan. Hak pembatalan dalam undang-undang dilakukan dalam lapangan yang luas dari pada hak pengesahan atau dengan kata lain penerapan pengawasan represif sacara luas yang tidak dibatasi oleh pengawasan preventif. Dalam penjelasan undang-undang ini dikatakan hak pengesahan dilakukan hanya terhadap halhal yang diatur dalam Pasal 7, 15 ayat 2, 16, 21, 27, 29, 31 dan lain sebagainya. Sementara hak pembatalan dilakukan terhadap semua perbuatan-perbuatan (putusan-putusan) Dewan Perwakilan Rakyat Daerah atau Dewan Pemerintah Daerah yang bertentangan dengan undangundang dan peraturan yang lebih tinggi tingkatannya atau bertentangan dengan kepentingan umum. ${ }^{26}$

\footnotetext{
26 Undang-Undang RI Nomor 22 Tahun 1948 Tentang Pemerintahan Daerah Tentang
} 
Namun istilah executive review sebenarnya tidak pernah terdapat dalam berbagai peraturan perundang-undangan yang mengatur pemerintahan daerah selama ini. Lantas timbul pertanyaan mengapa executive review harus dikaitkan dengan pengawasan? Ada beberapa alasan yang dapat dijelaskan mengenai hal tersebut. Pertama, istilah executive review diakui keberadaannya oleh MK sebagaimana terdapat dalam Putusan MK No. 56/PUUIV/2016. Sebagaimana telah diuraikan sebelumnya putusan ini mempunyai keterkaitan dengan Putusan MK No. 137/PUU-XIII/2015 yang dalam pertimbangan putusannya menyatakan pembatalan terhadap Perkada dapat dilakukan sepanjang itu merupakan pengawasan dan bukan pengujian. Berdasarkan pertimbangan hukum tersebut dalam pertimbangan hukum Putusan MK No. 56/PUU-IV/2016 menyatakan pembatalan terhadap Perkada dilakukan melalui executive review. Dengan demikian menurut hakim MK ada upaya executive review yang merupakan pengawasan. Kedua, istilah toetsingrecht apabila diterjemahkan dalam bahasa Indonesia akan menjadi istilah review hukum. Namun istilah review ini tidak identik dengan pengujian karena bisa juga berarti memandang atau menilai. ${ }^{27}$ Apabila review yang berarti memandang atau menilai dikaitkan dengan kewenangan Pemerintah Pusat sebagai organ negara dalam rangka mewujudkan sistem perundang-undangan nasional (pusat dan daerah) yang sinkron dan harmonis maka akan mengarah pada kewenangan pengendalian atau pengawasan. ${ }^{28}$ Jimly Asshidiqie meskipun di dalam beberapa bukunya menyebutkan executive review sebagai pengujian tapi

Penetapan Aturan-Aturan Pokok Mengenai Pemerintahan Sendiri Di Daerah-Daerah Yang Berhak Mengatur Dan Mengurus Rumah Tangganya Sendiri, Penjelasan Pasal 42

27 Jimly Asshiddiqie, Hukum Acara Pengujian Undang-Undang, Op. Cit, hal. 4 terkadang juga mengartikan sebagai pengendalian atau pengawasan. Menurutnya mekanisme kontrol norma hukum (legal norm control mechanism) dapat dilakukan melalui pengawasan atau pengendalian politik, pengendalian administratif, dan kontrol hukum (judicial). Kontrol politik dilakukan lembaga politik dimana mekanisme kontrolnya disebut legislative control atau legislative review. Mekanisme kontrol yang dilakukan oleh lembaga eksekutif disebut administrative control atau executive review. Adapun disebut legal control atau judicial review terhadap norma hukum (legal norm) apabila mekanismenya dilakukan oleh pengadilan. $^{29}$

Seperti halnya hak untuk menguji atau toetsingrecht, hak pengawasan atau toezichrecht juga di bahas oleh para ahli hukum dalam buku-buku mereka. Saiful Bahri Johan misalnya melihat kebebasan berotonomi selalu menyertakan pengawasan (toezicht). Menurutnya tidak ada otonomi tanpa pengawasan dan melaluinya merupakan cara untuk mengendalikan desentralisasi yang berlebihan. Ada dua jenis pengawasan yang dilakukan terhadap satuan pemerintahan otonom yaitu pengawasan preventif (preventief toezicht) dan pengawasan represif (repressief toezicht). Kedua jenis pengawasan tersebut dilakukan terhadap produk hukum dan tindakan tertentu organ pemerintahan daerah. Namun berbeda dengan undang-undang pemerintahan daerah yang pernah berlaku maupun yang masih berlaku saat ini dimana pengawasan preventif berkaitan dengan pengesahan menurut beliau justru tidak berkaitan dengannya melainkan bagaimana menjalankan pemerintahan yang baik (good

28 Pasal 4 ayat (1) Undang-Undang Dasar Negara Republik Indonesia Tahun 1945

29 Jimly Asshiddiqie, Prihal UndangUndang, Op. Cit, hal. 6-7 
governance). Sementara pengawasan represif adalah wewenang pembatalan (vernietiging) atau penangguhan (schoorsing).$^{30}$ Pembatalan produk hukum bukan hanya dapat dilakukan melalui pengujian (toetsing) tapi juga dapat dilakukan melalui upaya pengawasan (toezicht). Titik berat perbedaan pembatalan diantara keduanya diletakan pada inisitif dimana pada pengawasan represif (repressief toezicht) pembatalannya dilakukan secara spontan (spontane vernietiging) yaitu pihak yang berwenang membatalkan dapat melakukan inisiatif sendiri tanpa menunggu pihak yang ketiga. Sedangkan pembatalan melalui pengujian merupakan pembatalan melalui perkara (judicial review- maksudnya) tidak dilakukan dengan spontan atau dengan inisitif sendiri melainkan menunggu apabila ada pihak-pihak yang memperkarakannya. ${ }^{31}$

Berdasarkan hal tersebut executive review yang berupa pembatalan Perda semestinya oleh hakim MK dapat dilihat sebagai suatu pengawasan bukan pengujian sebagaimana hal tersebut dapat dilakukan terhadap pembatalan Perkada. Membedakan perlakuan executive review terhada Perda dan executive review terhadap Perkada dengan pertimbanganpertimbangan yang dibuat oleh hakim MK merupakan suatu kesalahan karena telah mengaburkan esensi dari makna negara kesatuan sebagaimana diatur dalam Pasal 1 ayat (1) Undang-Undang Dasar Negara Republik Indonesia Tahun 1945. Berdasarkan hasil analisis yang telah dilakukan belum ada satupun yang dapat dijadikan alasan yang paling kuat dari pertimbangan hukum hakim MK untuk membedakan perlakuan executive review terhada Perda dan executive review

\footnotetext{
${ }^{30}$ Teuku Saiful Bahri Johan, Politik Negara Atas Pluralitas Hukum Dalam Penyelenggaraan Pemerintahan Daerah, Deepublish, Yogyakarta, 2015, hal. 11-12
}

terhadap Perkada. Baik Perda maupun Perkada sama-sama merupakan salah satu dari jenis peraturan perundang-undangan yang diakui dalam sistem perundangundangan nasional oleh karena itu sebagaimana layaknya suatu kebijakan yang bersifat pengaturan (regeling) mempunyai karaktek berlaku mengikat umum apabila telah memenuhi prosedur pengundangan. Selain itu baik Perda maupun Perkada sama-sama merupakan jenis peraturan perundang-undangan yang merupakan bagian dari kebijakan daerah yang telah diakui sejak masa orde lama hingga saat ini dalam undang-undang pemerintahan daerah, yang dengannya dapat dilakukan pengawasan baik preventif seperti pengesahan maupun represif yang berupa pembatalan (vernietiging). Oleh karena itu semestinya executive review yang berupa pembatalan Perda semestinya dapat dimaknai sebagai hak pengawasan (toezichtrecht) sebagaimana halnya executive review terhadap Perkada.

Dalam pertimbangan hukum Putusan No. 137/PUU-III/2015 dikatakan bahwa pembatalan terhadap Perkada dapat dilakukan oleh Pemerintah Pusat karena merupakan produk dari satuan bestuur yang lebih rendah. Dalam lingkungan bestuur pembatalan Perkada merupakan wujud pengawasan satuan bestuur yang lebih tinggi terhadap satuan bestuur bestuur yang lebih rendah dan bukan sebagai upaya pengujian. Pertimbangan yang demikian kemudian semakin diperkuat dengan pertimbangan hukum Putusan No. 56/PUUIV/2016 yang menyatakan Perkada merupakan keputusan kepada daerah atau keputusan tata usaha negara sehingga pembatalan Perkada melalui executive review yang berada dalam lingkup fungsi administrasi negara yang dapat saja

31 Ni'matul Huda, Pengawasan Pusat Terhadap Daerah Dalam Penyelenggaraan Pemerintahan Daerah, FH UII Press, Yogyakarta, 2007, hal, 100 
dilakukan dan tidak bertentangan dengan Undang-Undang Dasar Negara Republik Indonesia Tahun 1945. Artinya berdasarkan kedua pertimbangan hukum dalam dua putusan berbeda tersebut pembatalan Perkada dapat dilakukan Pemerintah Pusat melalui mekanisme pengawasan karena masuk dalam fungsi administrasi negara. Terhadap pertimbangan yang demikian maka akan timbul pertanyaan mengapa executive review terhadap Perda tidak dapat dilakukan padahal apa yang diatur didalamnya merupakan penyelenggaraan atas urusan pemerintahan yang masuk dalam lingkup fungsi pemerintahan (bestuur). Sebagaimana amanat konstitusi Perda dapat dibentuk oleh Pemerintahan Daerah untuk menyelenggarakan otonomi daerah dan tugas pembantuan. Otonomi daerah yang merupakan hak, wewenang, dan kewajiban daerah tersebut berkenaan dengan urusan pemerintahan yang dengan demikian termasuk dalam domain administrasi negara juga. Adanya keterkaitan antara Perda dengan bidang administrasi negara menurut Enny Nurbaningsih merupakan implikasi dari hubungan pusat dan daerah dalam sistem otonomi yang hanya menyangkut di bidang penyelenggaraan administrasi negara. Oleh karena hubungan yang terbatas pada bidang yang demikian maka oleh Pemerintahan Daerah yaitu Kepala Daerah dan DPRD melakukan pengaturan di dalam Perda hanya terbatas mengatur segala hal ihwal bidang administrasi negara. Oleh karena itu Perda bersifat administratiefrechtelijke dan bukan staatsrechtelijke. ${ }^{32}$

Sebagai salah satu jenis peraturan perundang-undangan di tingkat daerah, Perda yang memuat urusan pemerintahan yang merupakan bidang hukum administrasi negara (administratiefrechtelijke) tentunya juga menimbulkan hubungan antara atasan dan

\footnotetext{
32 Enny Nurbaningsih, Problematika Pembentukan Peraturan Daerah Aktualisasi
}

bawahan. Seperti yang pernah disampaikan sebelumnya Putusan MK No. 137/PUU$\mathrm{XIII} / 2015$ sempat menyinggung antara pemerintahan atasan dan pemerintahan bawahan. Pada halaman 204 putusan tersebut disebutkan yang termasuk pemerintahan pusat sedangkan pemerintahan bawahan merupakan pemerintahan daerah provinsi dan pemerintahan daerah kabupaten dan kota. Jelasnya pertimbangan hukum tersebut berbunyi sebagai berikut:

"Dalam perspektif negara kesatuan (unitary state, eenheidsstaat) adalah logis untuk mengembangkan pengertian bahwa pemerintahan atasan berwenang melakukan kontrol terhadap unit pemerintahan bawahan. Artinya pemerintahan pusat dalam konteks NKRI berdasarkan UUD 1945 tentu dapat dikatakan mempunyai kewenangan untuk mengontrol unit-unit pemerintahan daerah provinsi ataupun pemerintahan daerah kabupaten dan kota. Demikian juga pemerintahan daerah provinsi juga dapat diberi kewenangan tertentu dalam rangka mengendalikan jalannya pemerintahan daerah kabupaten dan kota dibidang pengaturan. Yang dikendalikan atau dikontrol oleh pemerintahan atasan itu antara lain misalnya melalui kewenangan untuk melakukan "executive abstract preview", bukan mekanisme "review" atas peraturan daerah yang sudah berlaku mengikat untuk umum. Oleh karena itu terhadap peraturan daerah sebagai produk legislatif di daerah, sebaiknya hanya di "preview" oleh pemerintahan atasan apabila statusnya sebagai rancangan peraturan daerah yang belum mengikat umum. Jika peraturan daerah itu sudah mengikat umum, maka sebaiknya yang mengujinya adalah lembaga peradilan sebagai pihak ketiga yang sama sekali tidak terlibat dalam proses pembentukan peraturan daerah yang

Wewenang Mengatur Dalam Era Otonomi Luas, PT. RajaGrafindo Persada, Jakarta, 2019, hal. 232 
bersangkutan sesuai dengan sistem yang dianut dan dikembangkan menurut UUD 1945 yakni "centralized model of judicial review", bukan "decentralized model ", seperti ditentukan dalam Pasal 24A ayat (1) dan Pasal 24C ayat (1) UUD 1945."33

Jadi urusan pemerintahan yang termasuk dalam bidang hukum administrasi negara (administratiefrechtelijke) dimana Pemerintahan Daerah yang juga menyelenggarakan urusan demikian sesuai dengan kewenangannya merupakan subordinasi Pemerintah Pusat sehingga pengendalian dan pengawasan oleh Pemerintah Pusat terhadap Perda sebagai sesuatu yang logis tetap ada dalam negara kesatuan. Hanya saja hakim MK melihat pengendalian atau pengawasan yang dilakukan Pemerintah Pusat terhadap Perda hanya dimungkinkan dalam bentuk "executive abstract preview" bukan "executive abstract review". Kondisi ini menjadikan pertimbangan hukum hakim MK dalam Putusan No. 137/PUUXIII/2015 tidak konsisten karena terhadap Perda dan Perkada ada perlakuan yang berbeda. Executive review terhadap Perkada oleh Pemerintah Pusat dapat dilakukan padahal sebagaimana halnya Perda juga mempunyai sifat yang berlaku mengikat untuk umum apabila telah memenuhi prosedur yang ditentukan dalam pembentukan peraturan perundangundangan. Perda dan Perkada juga berada dalam lapangan bidang hukum yang sama yaitu hukum administrasi negara (administratiefrechtelijke) dimana hubungan Pemerintah Pusat dan Pemerintahan Daerah merupakan hubungan atasan dan bawahan. Oleh karena Pemerintahan Daerah merupakan subordinasi atau bawahan Pemerintah Pusat maka seharusnya urusan pemerintahan yang diatur dalam Perda seharusnya dapat pula

\begin{tabular}{lllr}
\hline 33 & Mahkamah & Konstitusi & Republik \\
Indonesia, & Putusan & Nomor & 137/PUU- \\
XIII/2015,Op.Cit, hal. 204 & &
\end{tabular}

dilakukan executive abstract review disamping executive abstract preview sebagaimana layaknya pengawasan yang dilakukan terhadap Perkada.

Selain semestinya hakim MK memperlakuan sama antara Perda dengan Pekada, dalam pembahasan juga telah dibuktikan bahwa upaya review yang dilakukan terhadap produk hukum tidak selalu dilihat sebagai upaya pengujian melainkan juga dapat berupa pengawasan. Sejarah ketatanegaran Indonesia telah memperlihatkan sejak masa orde lama hingga orde reformasi dalam perundangundangan yang mengatur penyelenggaraan pemerintahan daerah, pengawasan (toezicht) yang dilakukan Pemerintah Pusat terhadap produk hukum daerah seperti Perda dapat dilakukan dalam bentuk pembatalan (vernietiging). Hak pengawasan (toezichtrecht) adalah sesuatu yang berbeda dengan hak pengujian (toetsingrecht) karena hak pengawasan merupakan konsekuensi dari berlakunya Pasal 4 ayat (1) Undang-Undang Dasar Negara Republik Indonesia Tahun 1945 sedangkan hak pengujian merupakan turunan dari Pasal 24A ayat (1) dan 24C ayat (1) Undang-Undang Dasar Negara Republik Indonesia Tahun 1945. Hak pengawasan lahir karena tanggung jawab penyelenggaraan pemerintahan di Indonesia pada hakikatnya ada ditangan Presiden oleh karena Pasal 4 ayat (1) Undang-Undang Dasar Negara Republik Indonesia Tahun 1945 menjadikan Presiden sebagai pemegang kekuasaan pemerintahan. ${ }^{34}$ Sementara hak pengujian merupakan kompetensi mutlak bagi lembaga peradilan karena Pasal 24A ayat (1) dan 24C ayat (1) Undang-Undang Dasar Negara Republik Indonesia Tahun 1945 hanya mengenal dua lembaga yang melakukan pengujian di Indonesia yaitu

34 Mahkamah Konstitusi Republik Indonesia, Putusan Nomor 87/PUU-XIII/2015, 13 Oktober 2016, hal. 50 
Mahkamah Agung dan Mahkamah Konstitusi. Apabila hak pengawasan diberikan untuk menegakkan negara kesatuan maka hak pengujian diberikan untuk menegakkan negara hukum. Oleh karena itu memang tepat apabila pertimbangan hukum putusan MK menyatakan terhadap pengujian peraturan perundang-undangan di Indonesia berdasarkan UUD 1945 hanya mengenal centralized model of judicial review karena tidak ada lembaga lain di luar lembaga peradilan yang mempunyai kewenangan tersebut. Oleh karena itu pula pembatalan Perda yang dilakukan oleh Pemerintah Pusat tidak akan pernah menegasikan peran dan fungsi Mahkamah Agung karena pembatalan Perda dilakukan dalam bentuk executive review yang merupakan hak pengawasan dan bukan hak pengujian. ${ }^{35}$

\section{KESIMPULAN}

Dalam suatu putusan khususnya putusan yang dikeluarkan oleh hakim Mahkamah Konstitusi peran pertimbangan hukum sangat esensial bagi lahirnya suatu amar putusan. Melalui analisa terhadap pertimbangan hukum maka dapat dapat memahami mengapa hakim dalam suatu persidangan di MK memutuskan mengabulkan atau menolak permohonan pemohon sekaligus menyatakan ayat, pasal atau beberapa pasal tidak mempunyai kekuatan hukum yang mengikat jika menyangkut pengujian undang-undang. Singkatnya pertimbangan hukum mencerminkan argumentasi dan pendapat hakim terhadap amar putusan yang dibuatnya. Putusan MK yang telah membatalkan kewenangan Menteri dan Gubernur sebagai wakil pemerintah pusat dalam melakukan executive review terhadap Perda apabila dilihat dalam pertimbangan hukumnya terdapat dua hal yang

35 R.D.H Koesoemahatmadja, Pengantar Ke Arah Sistem Pemerintahan Daerah Di Indonesia, cet. pertama, Binacipta, Bandung, 1979, hal.100 mendasarinya yaitu karena hakim MK menganggap Pasal 251 UU No. 23 Tahun 2014 Tentang Pemerintahan Daerah telah menyimpangi logika dan bangunan negara hukum dan telah menegasikan peran dan fungsi MA sebagai lembaga yang berwenang melakukan pengujian peraturan perundang-undang dibawah undangundang terhadap undang-undang. Kedua dasar pertimbangan hukum tersebut didasarkan pada tiga prinsip yaitu prinsip NKRI, prinsip desentralisasi dan otonomi daerah, dan prinsip kekuasaan kehakiman dan negara hukum.

Di dalam prinsip kekuasaan kehakiman dan negara hukum hakim MK menilai kewenangan Menteri dan Gubernur sebagai wakil pemerintah pusat dalam melakukan executive review terhadap Perda telah melanggar Pasal 24A ayat (1) UUD Negara Republik Indonesia Tahun 1945 dan Pasal 9 ayat (2) UU No. 12 Tahun 2011 Tentang Pembentukan Peraturan Perundang-Undangan. Ketika membandingkan executive review terhadap Perda dan excutive review terhadap Perkada pertimbangan hukum hakim MK ternyata tidak konsisten jika ditinjau dari prinsip kekuasaan kehakiman dan negara hukum serta ditinjau dari kekuatan mengikatnya suatu peraturan perundang-undangan. Selain itu sejak undang-undang yang mengatur penyelenggaraan pemerintahan daerah di masa orde lama hingga di masa orde baru ternyata pembatalan perda merupakan suatu kelaziman karena pembatalan menurut undang-undang tentang pemerintahan daerah lebih dilihat sebagai hasil dari pengawasan dan bukan pengujian. Artinya Pemerintah Pusat membatalkan Perda dengan executive review karena lahir dari hak pengawasan dan bukan pengujian. Sehingga pertimbangan hukum hakim MK sangat 
salah apabila menganggap executive review yang dilakukan oleh Pemerintah Pusat sebagai pengujian.

\section{DAFTAR PUSTAKA}

Asshiddiqie, Jimly. Hukum Acara Pengujian UndangUndang. Konstitusi Press, Jakarta. 2006. , Jimly. Prihal Undang-Undang. Rajawali Pers. Jakarta. 2010.

, Jimly dan M. Ali Syafa'at. Teori Hans Kelsen Tentang Hukum. Sekretariat Jenderal \& Kepaniteraan Mahkamah Konstitusi RI. Jakarta. 2006.

Busroh, Abu Daud. Ilmu Negara. Cetakan Pertama. Bumi Aksara. Jakarta. 1990.

Koesoemahatmadja, R.D.H. Pengantar Ke Arah Sistem Pemerintahan Daerah Di Indonesia, cet. pertama. Binacipta. Bandung. 1979

Gadjong, Agussalim Andi. Pemerintahan Daerah: Kajian Politik dan Hukum. Ghalia Indonesia. Bogor. 2007.

Johan, Teuku Saiful Bahri. Politik Negara Atas Pluralitas Hukum Dalam Penyelenggaraan Pemerintahan Daerah. Deepublish. Yogyakarta. 2015.

Manan, Bagir. Dasar-Dasar Perundang-Undangan Indonesia. Ind-Hil,Co. Jakarta. 1992.

Nasution, Bahder Johan. Metode Penelitian Ilmu Hukum. Mandar Maju. Bandung. 2008.

Nurbaningsih, Enny. Problematika Pembentukan Peraturan Daerah Aktualisasi Wewenang Mengatur Dalam Era Otonomi Luas. PT. RajaGrafindo Persada. Jakarta. 2019

Soehino. Ilmu Negara. Liberty. Yogyakarta. 2000.

Sudarsono. Kamus Hukum. Cet. Keempat. PT. Rineka Cipta dan PT. Bina Adiaksara. Jakarta. 2005.

Indonesia. Undang-Undang Dasar Negara Republik Indonesia Tahun 1945

Undang-Undang Nomor 22 Tahun 1948 Tentang Penetapan Aturan-Aturan Pokok
Mengenai Pemerintahan Sendiri Di

Daerah-Daerah Yang Berhak Mengatur

Dan Mengurus Rumah Tangganya Sendiri Undang-Undang Nomor 1 Tahun 1957 Tentang Pokok-Pokok Pemerintahan Daerah

Penetapan Peraturan Presiden Nomor 6 Tahun 1959 Tentang Pemerintah Daerah

Undang-Undang Nomor 18 Tahun 1965 Tentang Pokok-Pokok Pemerintahan Daerah

Undang-Undang Nomor 5 Tahun 1974 Tentang Pokok-Pokok Pemerintahan Di Daerah

Undang-Undang Nomor 22 Tahun 1999 Tentang Pemerintahan Daerah

Undang-Undang Nomor 24 Tahun 2003 Tentang Mahkamah Konstitusi sebagaimana telah diubah dengan Undang-Undang Nomor 8 Tahun 2011 Tentang Perubahan Atas Undang-Undang Nomor 24 Tahun 2003 Tentang Mahkamah Konstitusi

Undang-Undang Nomor 32 Tahun 2004 Tentang Pemerintahan Daerah

Undang-Undang Nomor 12 Tahun 2011 Tentang Pembentukan Peraturan PerundangUndangan sebagaimana telah diubah dengan Undang-Undang Nomor 15 Tahun 2019 Tentang Perubahan Atas Undang-Undang Nomor Nomor 12 Tahun 2011 Tentang Pembentukan Peraturan Perundang-Undangan.

Undang-Undang Nomor 23 Tahun 2014 Tentang Pemerintahan Daerah sebagaimana telah diubah beberapa kali terakhir dengan Undang-Undang Nomor 9 Tahun 2015 Tentang Perubahan Kedua Atas Undang Undang Nomor 23 Tahun 2014 Tentang Pemerintahan Daerah.

Putusan Mahkamah Konstitusi Nomor 87/PUU$\mathrm{XIII} / 2015$

Putusan Mahkamah Konstitusi Nomor 137/PUU$\mathrm{XIII} / 2015$

Putusan Mahkamah Konstitusi Nomor 56/PUU$\mathrm{XIV} / 2016$ 